\title{
Knowing and Loving: Public Engagement beyond Discourse
}

\author{
Sarah R Davies
}

This article builds on STS scholarship on public engagement with science to reflect on the role of the non-discursive, arguing that this has been under-studied in analyses of engagement. I make this point in three stages: I review literature that has analysed public engagement, suggesting that it can be understood as focusing on process, effects, framing or context, and has therefore largely ignored features such as site, materiality and affect; I draw on recent work in political theory to emphasise the importance of the emotional and creative within deliberation; and I present an example of what it might look like to be attentive to emotion in public participation by exploring the role of pleasure in engagement activities. As a whole this discussion is used to point to a lacuna in studies of public engagement, and to suggest some implications for both practice and empirical research.

Keywords: public engagement, deliberation, non-discursive, emotion

\section{Introduction}

I want, in this paper, to reflect on a single, but I believe important, point, which is that STS-informed practice and analysis of public engagement with science has tended to focus on the discursive to the exclusion of other features, such as embodiment, materiality, affect and place. ${ }^{1}$ Thus we - as scholars of public participation - have planned engagement events and deliberative activities that focus on enabling the equitable exchange of reasoned arguments, and have analysed these events with an eye to the talk that appears within them - looking at the ways that science, publics or citizenship are constituted, for instance, or at the subject roles that participants take up. My argument here is that in doing so we are missing important aspects of the practice of public participation. We should understand public engagement with science - of all types and varieties ${ }^{2}$ - as not only spaces in which language is at play, but as processes constituted by embodied experience, objects, and emotions. We should be attentive to both the material 'stuff' of public engagement activities and to their affective content - for instance as expressed in disruptive rationalities and emotional tone.

In arguing thus I am building on Matthew Harvey's 2009 paper, 'Drama, Talk, and Emotion: Omitted Aspects of Public Participation', as well as on a much larger body of work which has analysed 
burgeoning European moves towards public engagement with science and technology. But I want also to draw on recent work from deliberative theory which has similarly argued for a move away from 'reasoned argument' to an openness to other modes of interaction. I develop my argument in three parts. I start by reviewing the significant corpus of STS literature which has emerged around the analysis of public participation and engagement, suggesting that such analysis has tended to focus on one of four different concerns, none of which is particularly attentive to the material practices and affective repertoires of engagement. In the second section I draw on thinking from deliberative theory to argue that there is (and indeed should be) more going on within public participation than can be captured by stimulation of and attention to discourse, and suggest some implications of this for our thinking on the practice of public engagement. And in the final section I focus on how our analyses might focus on the non-discursive by discussing one under-studied aspect of engagement: emotions of pleasure and delight. Drawing on theoretical and empirical studies in STS, I outline some of the reasons we may be hesitant to make such emotions the focus of our studies of engagement, and some ways in which we might start to take them seriously as components of public participation in science. In a brief conclusion, I draw these strands together. I start, then, by turning to some of the key ways in which public engagement has been analysed and critiqued in the STS literature.

\section{Analysing Public Engagement}

The turn to public engagement, participation and dialogue on science that has taken place over the last two decades has been widely discussed (see, for instance,
Elam \& Bertilsson, 2003; Irwin \& Michael, 2003; Jasanoff, 2003). While identifying the triggers and outcomes of this turn remains problematic (Delgado et al., 2010; Gregory \& Lock, 2008; Irwin, 2006; Lengwiler, 2008), it seems clear that, in European science policy and communication at least, ${ }^{3}$ there has been a shift towards the language and to some extent the practice - of "the involvement of nonscientists, laypeople, or citizens in science and technology" (Lengwiler, 2008: 187). Scholars have sketched out frameworks for what such involvement should look like (PytlikZillig and Tomkins 2011), and have written about the tensions inherent in seeking to put these into practice (Delgado et al 2010). I am, however, concerned here with the way in which activities and processes that fall under the rubric of public engagement have been analysed and assessed: what those in STS have said, in other words, about what public engagement looks like as it is carried out. My argument is that analysis so far has focused on four different areas - or, better, has emphasised one of four different (though overlapping) concerns. These are, briefly: the process, effects, framing, and contexts of public engagement with science. I will sketch out the literature on each of these below.

Most work has been done on the first of these concerns, in examining process - exploring what happens within public engagement processes. Here the paradigmatic work is that on evaluation of participatory events or structures (e.g. Rowe \& Frewer, 2000; Rowe et al., 2004; Horlick-Jones et al., 2006; 2007; Neresini \& Bucchi, 2010), which tends to take a normative perspective by outlining what should have happened in any particular process, and then to describe what actually did. Rowe and colleagues, for instance, outline nine evaluation criteria ('representativeness, independence, early 
involvement, influence, transparency, resource accessibility, task definition, structured decision making, and costeffectiveness'; 2004: 93) before assessing how one process - a Food Standards Agency-run stakeholder consultation matched up to these. Similarly, HorlickJones et al. (2006) sketch out the aims and objectives of the UK's GMNation? public debate before considering its success or otherwise (it was, they say, "flawed in a number of important ways", Horlick-Jones et al., 2006: 283). Evaluation criteria and reports also emerge from outside of the STS community, including in practitioner literature (see Bonney et al., 2009; Gammon \& Burch, 2003; McCallie et al., 2007).

Similar issues emerge from more general analyses of engagement-asprocess. Procedural issues, such as the representativeness of participants, are a consistent theme: participant motivations (Kleinman et al., 2011), the knowledges and deliberative behaviours at play within engagement (Burri, 2007; 2009; Endres, 2009), and the discursive strategies participants use (Besley et al., 2008; Davies et al., 2006; Walmsley, 2010) have also all been discussed. The tracings of power and of expertise within public engagement (Blok, 2007; Davies, 2013; Felt et al., 2009; Kerr et al., 2007) are a key emphasis. Other scholars have examined how the practice of public engagement matches up not to particular evaluation frameworks but to different conceptualisations of participation (Carolan, 2008; Kerr et al., 2007) or to deliberative theory as a whole (Davies et al., 2006). Many of these assessments are pessimistic. The gist of work on process has been to demythologise and complicate the very notion of public participation in science, showing - whether through the failure to meet stated aims, the presence of enduring inequities, or simply the complexity of moment by moment interaction - that the practice of participation is by no means as straightforward as has occasionally been implied. As Delgado et al. (2010) write, "while our mentors presented us with the idea that public participation was the solution, we increasingly feel that we have inherited it as the problem" (Delgado, 2010: 826; emphasis in original).

Out of research on process as a whole, two further concerns have emerged as particularly important. There has, first, been an enduring - and often critical - interest in the effects of participatory activities. Work in this area has sought to examine the efficacy of policy-oriented engagement and the relationship between such activities and the institutional structures they are embedded within: many accounts have, for instance, noted the limitations of deliberative processes as a means of publics influencing or shaping government or scientific policy (Hagendijk \& Irwin, 2006; Katz et al., 2009; Lyons \& Whelan, 2010; Schibeci et al., 2006). In the case of the much-studied GM Nation?, for instance, it was suggested that key decisions had been made in advance by the UK government and could in no way be affected by the outcomes of the public debate (Horlick-Jones et al., 2006; Irwin, 2006; Mayer, 2003). Summing up the work of the STAGE ('Science, Technology and Governance in Europe') project, which reviewed case studies of public engagement in 26 countries, Hagendijk and Irwin (2006: 176) write that:

\footnotetext{
...in most countries, and in most cases, engagement initiatives are kept at arm's length from formal decision-making. Understandably, governments will not guarantee in advance their response to deliberative recommendations. ... However, a refusal to take outcomes seriously risks undermining public trust.
} 
While more recent work has tended to take a broader perspective in defining efficacy - suggesting, for instance, that impacts on citizens and citizenship may be as important as those on policy (Powell \& Kleinman, 2008) - the sense that, without definite outcomes, current interest in participation is a smokescreen for increasing public trust without increasing public accountability remains a pervasive one (Dryzek et al., 2009; Wynne, 2006).

A third and related analytical focus has been the framings embedded within engagement processes, and in particular the ways in which different actors and concepts have been constituted through public participation. A key emphasis, derived particularly from the work of British 'critical PUS' scholars (Irwin \& Michael, 2003), has been the ways in which "scientific knowledge unwittingly performs its imagined publics in normative ways" in and through engagement (Wynne, 2006: 219, emphasis in original). Such performances often continue to frame lay publics as deficient or lacking in some way. Irwin has written about lingering 'deficit model' perspectives within one public consultation, which meant that citizens were framed as ignorant (Irwin, 2001), while other work has repeatedly identified cases in which scientific knowledge was $a$ priori assumed to be more valuable than 'lay' or 'local' knowledges and perspectives (Goven, 2003; Kurian \& Wright, 2010; Martin, 2007; Schibeci \& Harwood, 2007). Indeed, shifting constructions of the publics of participation - as pure, partisan, mobile, engaged or distinctively 'nonscientific' - have been something of a theme in recent literature (Braun \& Schultz, 2010; Gottweiss, 2008; Kurath \& Kisler, 2009; Lezaun \& Soneryd, 2007). As with interest in the effects of participation, the concern here is not merely how different actors are framed within public engagement, but what the impacts of these framings are. Lassen et al. (2011), for instance, are able to trace the ways in which agency is subtly removed from citizens and focused on other actors (such as policy makers) through their discourse analysis of two participatory fora around climate change. For Wynne, the limits and constraints placed upon publics by scientific imaginations of them - as embedded within calls for and practices of public engagement - are a central challenge to the science and society relationship. The problem, he writes, is technoscience's tendency to:

impose its own tendentious and debatable definitions of public meanings onto the public, then misreading the reasons for negative or sceptical public reactions from within the same unquestioned (science- or risk-centred) premises about public meaning, rather than recognizing that the original premises may be worth revising - such as the premise that publics are concerned only about 'risk' and not, for example, about upstream (usually unaccountable) driving human visions, interests and purposes in the science and innovation itself. (Wynne, 2006: 217)

It is not necessarily science that is being rejected, in other words, within public controversies or debates - but rather the limited versions of public concern and citizenship that are presented within public participation.

Finally, recent research has begun to explore the broader contexts within which participation occurs, and to discuss the ways in public engagement is inflected by the cultures - political, national, scientific, local - which surround it. There is a growing awareness, for instance, of the importance of national culture in the imagination and practice of engagement activities (Horst \& 
Irwin, 2010; Macnaghten \& Guivant, 2010), and of the different models of participation and citizenship which are at play within deliberative activities (Felt et al., 2008). The political economies of participation are also starting to be unpicked through attention to both the linear models of technological development which are implicit in talk of 'upstream engagement' (Joly \& Kaufmann, 2008) and wider economic and political cultures. Joanne Goven's analysis (2006) of New Zealand's Royal Commission on Genetic Modification emphasises the need for researchers of such processes to look beyond immediate concerns of 'success' or 'failure' to the broader framing impacts of the surrounding political-economic culture and, in particular, neoliberalisation. Goven argues that the concepts - such as 'scientific citizenship' - mobilised in public participation are profoundly influenced by wider political dynamics; similarly, Charles Thorpe has traced the interplay between the turn to public engagement with science in the UK and the co-option of publics within post-Fordist markets (Thorpe, 2010; also Horlick-Jones et al., 2007; Thorpe \& Gregory, 2010). Such scholarship is increasingly locating public participation within pervasive, but largely invisible, political dynamics. Noting, as have others, the connections between discourses of public participation and those of the commercialisation of science (Irwin, 2006; Pestre, 2008), Thorpe (2010: 404) writes that:

public engagement with science and technology should be understood as an aspect of this broader Third Way movement toward 'democratization' as a strategy of governance of, and through, culture. ... In particular, public engagement gains its policy rationale from the idea that it is a 'new politics' appropriate to the 'new economy.'
Such work thus continues the task of de-mythologising engagement and of emphasising its contingency. Just as studies of 'process' indicate the fragile, moment by moment construction of deliberative talk (Davies et al., 2006), analyses of the contexts of participation show just how tightly any event or process is entangled with the cultures in which it is situated.

\section{Public Engagement beyond Discourse}

While such de-mythologisation is vital in a context which can too often cleave to unrealisable ideals of deliberation (Delgado et al., 2010), what the research described above does not do is pay much attention to the non-discursive - to the role of, for instance, the emotional, material or creative within public engagement. It is striking, for instance, that the concerns I have identified in the public engagement literature (of process, effects, framings, and context) are essentially immaterial. They are grounded in the analysis of discourse of policy documents, interview transcripts, and the talk of public engagement events; and they are concerned with rather abstract entities: institutions, policies, consensus, "institutional body language" (Wynne, 1992). While the accounts they give of the power dynamics of deliberation, or of its entanglement with neoliberal assumptions, are pressing (not least because they are too often ignored or misheard), we are, I think, justified in asking: is there anything else at play within these processes?

My answer to this is yes: as Harvey has outlined (2009), dialogue events are "dramatic and emotional", and their reduction to a series of evaluation criteria (or, we might add, a consensus report or discourse analysis) misses the fact that they are "sites of intense emotion, argument, tension, and humor" (Harvey, 2009: 146) and, indeed, that these dynamics will shape 
their progress and outcomes. ${ }^{4}$ Equally, they are sites, full of objects and bodies, and they deal with experiences and knowledges (both 'lay' and 'scientific') which are similarly embodied and ordered through material practices. Thus, for instance, they take place in particular kinds of sites and spaces (a shopping centre, conference venue, venerable scientific institution, or café), produce different emotions (indifference, enthusiasm, annoyance, embarrassment, boredom), and deal with very different forms of embodied knowledge (the expertise of the lab scientist, the self-awareness of the patient in pain, the mundane rituals of everyday life in a technological society). These features will surely shape the practice of public participation, and are thereby also worthy of attention.

I want to expand on this point by discussing some recent work in deliberative theory. Before I do this, however, I need to clarify my terms somewhat. I have been using notions such as 'affect' and 'emotion' disingenuously, lumping all non-discursive aspects of interaction together in, more or less, the same pot. My central point is certainly that all such non-discursive features and modes are interesting for us as analysts, whether sites, bodies, emotions, aesthetics, or objects. But the disadvantage of this one-pot approach is twofold: it sets up an distinction between 'discourse' and 'the non-discursive' which is too simplistic (Wetherell, 2012); and it occludes very real differences between notions such as affect and emotion (Tomkins, 1962). Many theorists of affect view affect and emotion as fundamentally different processes, with affect the primary, more basic 'pull' between bodies and objects and emotion a more sociologically loaded experience (Massumi, 1995; Sedgewick \& Frank, 1995). However, in practice it is often not easy to draw the line between notions such as materiality, embodiment and affect: for Massumi, for example, affect is "irreducibly bodily" (Massumi, 1995: 89), such that the study of affect - what Seigworth and Gregg have described as an inventory of shimmers', a discussion of "intensities that pass body to body" (Seigworth \& Gregg, 2010: 1) - cannot be separated from the weight of the material world. ${ }^{5}$ There are, then, good reasons for accepting that focusing on one of these 'non-discursive' aspects will involve some attention to the others. For the purposes of this discussion I have therefore largely ignored differences between, say, embodiment and materiality, as well as the distinction between affect and emotion, to operate within an deliberately simplified framework which gives scope for my wider point: that practice and analysis in public engagement should go beyond discourse. $^{6}$

It is also important to note that much of this thinking is not new to STS, which as a discipline has been influential in both the material and affective turns in recent social theory (see Bennett, 2009; Bryant et al., 2011; Ingold, 2010; Miller, 2005; Gregg \& Seigworth, 2010). STS scholarship has drilled home the importance of materiality in the production of scientific knowledge, and indeed in sociality more generally (Latour, 2000), and has paid attention to the materialities of 'everyday publics' and politics (Braun \& Whatmore, 2010; Marres, 2012) and of public engagement with mundane technologies (Michael, 2011). It is therefore surprising that this attention has, by and large, not been further brought to bear on recent moves towards dialogue and deliberation on science ${ }^{7}$ - and particularly so when one realises to what extent these concerns have risen to the fore in recent work in deliberative theory.

This literature is relevant because much of the 'deficit to dialogue' move within STS and engagement practice ultimately draws 
upon theories of deliberative democracy (see Davies et al., 2006; Elam \& Bertilsson, 2003; Hamlett, 2003). Thus Elam and Bertilsson (2003: 241) write, in discussing the turn from PUS to public engagement, that:

Deliberative democracy also appeals to the scientific community for its commitment to building political decisionmaking on 'rational consensus' rather than 'mere agreement'. The civilized vision of democratic politics that deliberative democracy supports is one of the unhurried exchange of arguments between reasonable persons guided by the principle of impartiality.

Deliberative theory has, indeed, traditionally espoused the "exchange of arguments between reasonable persons" (ibid). At its most basic it presents a model of democracy which is tied to "accountability and discussion" (Chambers, 2003: 308): it emphasises deliberation over processes of representation and voting (and is thereby readily linked to calls for participatory or direct democracy; see Fiorino, 1990; Hamlett, 2003). Deliberative processes are those in which participants "are amenable to changing their judgments, preferences, and views during the course of their interactions, which involve persuasion rather than coercion, manipulation, or deception" (Dryzek, 2000: 1; see also Cohen, 1989). It therefore brings different - and differing - actors together around a central problem, which they explore and seek consensus (or at least some kind of outcome-oriented endpoint) upon (Chambers, 2003). Deliberative theorists argue that such open, multi-vocal public debate will enable better decision making (Chambers, 2003; Cooke, 2000) and is a more authentic form of democracy (Dryzek, 2000).
There are therefore clear parallels with the way in which public engagement with science has been conceptualised (see, for instance, Rowe \& Frewer, 2004). There is, however, one difference. Within deliberative theory this 'ideal type' deliberation has been criticised and, through such critique, taken in a number of new directions. As yet, these later developments have been less well applied within thinking on public participation with science. For scholars such as Iris Marion Young and Lynne Sanders, for instance, deliberative theory's emphasis on reasoned argument is itself anti-democratic. Calls to deliberate, Sanders writes, imply the primacy of "rationality, reserve, cautiousness, quietude, community, selflessness, and universalism" (Sanders, 1997: 348) - connotations "which in fact probably undermine deliberation's democratic claims" (ibid). Young (2001) is similarly concerned with deliberation's hidden entanglements with power, in the shape of its assumption that the power dynamics of wider society can be 'bracketed' within a deliberative process such that equitable argument leads to just, reasonable, and consensusbased decisions. She uses the character of the activist - one who self-consciously rejects the opportunity to participate in deliberative processes, and instead acts on the margins of such processes in order to disrupt and problematise them - as a means of exploring the limitations of deliberation and the constraints in which it is enmeshed. Such limits include the need to operate within established political structures and the inevitable reproduction, within deliberative engagement, of hegemonic discourses. Ultimately, she writes, other modes of interaction are required in order to disrupt these taken-for-granted assumptions about the world: 
Because he [sic] suspects some agreements of masking unjust power relations, the activist believes it is important to continue to challenge these discourses and the deliberative processes that rely on them, and often he must do so by nondiscursive means - pictures, song, poetic imagery, and expressions of mockery and longing performed in rowdy and even playful ways aimed not at commanding assent but disturbing complacency. One of the activist's goals is to make us wonder about what we are doing, to rupture a stream of thought rather than weave an argument. (Young, 2001: 687.)

While for Sanders the model of quiet, considered argument implied by deliberative theory unjustly privileges those citizens adept in such interactional techniques (citizens who, as Elam and Bertilsson point out, also fit the model of the good scientist; 2003: 242), Young is more concerned with the limitations of such interaction in exposing hidden ideological commitments. The nondiscursive formats of creative intervention or street theatre, she suggests, are more effective at breaking into "a stream of thought" (Young, 2001). Both Young and Sanders ultimately suggest the value of going beyond reasoned argument to open deliberation up to more diverse forms of interaction: storytelling, for example, or polemic, or Young's "pictures, song, poetic imagery". Reasoned argument, in other words, is not enough. Good deliberation should incorporate space for emotional, creative - even disorderly modes of communication.

Such critiques have been influential, and are increasingly being taken on board by those concerned with the practice of deliberation. John Dryzek's (2000) discussion of deliberative democracy tellingly titled Deliberative Democracy and
Beyond - explicitly widens deliberative interactions to include any form of communication which is non-coercive ${ }^{8}$ and which can connect the particular to the general, while Bächtiger et al. (2010), in a summary of deliberative theory and practice, separate the field into two by distinguishing between that which "embodies the idea of rational discourse" and newer forms which "involve[s] more flexible forms of discourse" (p.33). And in more applied fields, such as urban planning, expectations of what deliberative engagement does and should look like have been radically widened to incorporate not only different forms of discourse but also artistic, dramatic or musical expressions of opinion or perspective (Sandercock, 2003). Within political theory the expectation is thus no longer that deliberation is necessarily the calm, strictly rational activity so attractive to scientists (Elam \& Bertilsson, 2003), but a process which is at once more open and more equitable though perhaps also more chaotic.

These developments have clear implications for public engagement with science. If STS has emphasised that science is inextricably intertwined with the material world and its affective powers (Latour and Weibel, 2005), recent deliberative theory indicates that these dimensions must and should play a key role in public participation. My argument here, then, becomes both normative and practiceoriented as well as analytical. We should not only be attentive to non-discursive features of public engagement within our analyses but, as practitioners, actively seek to design participatory processes which enable the expression of knowledges and perspectives in modes which go beyond the discursive. The importance of affect and materiality thus has implications for both the design and analysis of public participation. 
I want, in the next section, to briefly treat some of these implications for analysis by considering how we might become attentive to the role of interest and enthusiasm in public engagement with science. Before doing so, however, what might it mean to incorporate knowledges and modes of interaction that go beyond discourse into the design of participation and dialogue? While I cannot discuss this question in any detail (see Davies in press for a fuller treatment), there are a number of avenues that we might follow. We could take inspiration, for instance, from the existing work that has been done within deliberative theory. Iris Marion Young's emphasis on the power of the activist and the need for creative disruption (2001), for instance, might lead us to develop an openness to groups and individuals 'breaking in' and messing with our tidy, carefully designed deliberative processes (cf. Michael, 2012; Wehling, 2012). From traditional, public understanding of science-oriented science communication we might search out new formats - such as art-science collaborations (Webster, 2005), object-oriented engagement events (Birchall, 2011), or university and lab open days (Ward et al., 2008) - and explore how these different material and affective configurations might be incorporated into more straightforwardly discursive processes, such as consensus conferences. Or we could build on existing work within STS which has sought to emphasise or communicate affective or aesthetic dimensions of emerging science and technology - projects such as Maja Horst's Stem Cell NetWork - a Social Science Lab, ${ }^{9}$ which developed an immersive installation within which visitors could reflect on the contingency of scientific knowledge in activities such as game-playing or making themselves 'at home' in a model bedroom; or the UK project Synthetic Aesthetics, which investigates "shared and new territory between synthetic biology, art and design" through collaborations between social scientists, biologists, and artist-designers. ${ }^{10}$ All of these examples seem likely to help introduce different kinds of knowledge and experience into public participation, or to highlight aspects of science or everyday experience that are often occluded in deliberation. But this is, of course, a topic that requires further thought, experiment, and assessment.

\section{Knowing and Loving: Pleasure in Public Engagement}

Thus far I have summarised STS analysis of public engagement with science, arguing that the literature's emphases on process, framings, effects and contexts have tended to focus on the discursive aspects of these practices. I have also suggested, from recent thinking in deliberative theory and the material turn in STS, that aspects such as emotion, site, embodiment and creative intervention will and should be important features of public engagement. If this is the case, how should we go about analysing these dimensions? How, in other words, do we become attentive to the role of materialities, affects, and place in encounters between publics and science?

Again, there is not scope within this article for a programmatic methodology. ${ }^{11}$ Instead I want to present a case study of what it might look like to start to notice, and follow, these under-studied aspects of engagement. I will do this by focusing on the idea of pleasure - and, relatedly, enjoyment, delight, or interest - in public engagement with science. I want to make three points: that, firstly, STS scholarship has tended to be suspicious of anything that has emphasised pleasure within engagement, and as a result we have largely elided its expression from our data; that it is in fact 
a key way that participants understand public engagement; and that there are at least a couple of lines of thought, drawn from more theoretical accounts of interest and wonder, that might help us think about what its expression means and does. This is, then, not a final analysis, but an exploration of the ways in which we might start to 'rehabilitate' one particular emotion within our analyses. In reflecting on these issues I draw both on a number of previous research studies on the practice of public engagement with science in the UK - work that has included attending formal and informal dialogue events as a participant observer, interviewing (lay and specialist) participants, and talking with practitioners and organisers of deliberative activities (Davies, 2009; 2013a; 2013b) - and on the wider STS literature on engagement.

My starting point is the near invisibility of pleasure or enjoyment as features of extended empirical analysis of public engagement - certainly as a focus of such analysis. This derives, I would suggest, from the affective work that has been done around scientific citizenship over the last decades, and perhaps especially from public engagement's creation narrative of 'deficit to dialogue', which tells of a move from naïve public understanding of science (PUS) to enlightened participatory approaches (Elam \& Bertilsson, 2003; Gregory \& Lock, 2008). It is possible to read this history in terms of the emotional relations between science and its publics: Jon Turney, for instance, assessed PUS as undergirded by the assumption that "to know science is to love it", writing that "[o]ne of the motives for trying to improve people's understanding of science has been to increase public sympathy for science and scientists, and perhaps give those trying to introduce certain new technologies an easier ride" (Turney, 1998: 3). Here the cognitive ("understanding") is intimately and immediately tied to the affective ("sympathy"). Knowing leads to loving. Good citizens know about science, but that knowledge is not, in itself, the point. Rather, it is viewed as able to mediate love - and thereby emotional ties to science. In the context of the deficit to dialogue narrative, these emotional ties play a particular role: it is this twinning of knowledge and affection that is disrupted by critical social research (for instance, Irwin \& Wynne, 1996), leading, ultimately, to new models of science and society and to the contemporary emphasis on participation, dialogue and engagement.

It may seem, then, that the drive to inculcate love has been elided from scientific citizenship with the move to public participation and dialogue. But closer inspection reveals that new models of scientific citizenship also entail particular affective configurations. Indeed, I would suggest that modelling the good citizen as participant involves a simultaneous purging of emotion, through deliberative democracy's emphasis on reasoned argument, with an infusion of new affections, such as trust, confidence, and excitement. Thus on the one hand we have the influence (as discussed in the previous section) of theories of deliberation which view the good citizen as unbiased, reasoned, and measured. Elam and Bertilsson (2003: 244) write that:

Just as passion and outrage were necessarily absent from science according to the traditional Enlightenment model of science and society relations, so they can end up being rendered alien to the exercise of scientific citizenship by the alliance of PES with deliberative democracy. In the latter context, passion and outrage become not only threats to Truth, but also to the achievement of a Fair and Just scientific democracy. 
"Passion and outrage" are thereby excluded from scientific citizenship, which is framed as centring on participation in deliberative processes (the good citizen is now the one who participates, rather than the one who knows; the one who participates is cool, reasoned, unemotional). At the same time, however, it is clear that much of the flurry of interest in engagement which took place in the early 2000s in the UK was carried out with the expectation of increasing public trust (Wynne, 2006). Thorpe and Gregory, for instance, note:

That the affective condition of confidence is the desired outcome of participatory activity is repeated throughout British government statements on the topic ... Such statements, understood in the broader policy context in which they are situated, suggest that public engagement is being constructed as a technique for producing the public confidence regarded as essential to the stability of the 'innovation system'. (Thorpe \& Gregory, 2010: 286)

Here, then, publics are instilled with trust and confidence in science through participation: as Thorpe and Gregory (2010) suggest, "participatory activity" is fundamentally about ensuring an "affective condition of confidence". We might therefore understand contemporary scientific citizenship, as it is produced within the drive for public engagement, as a hybrid of two configurations: the passionless deliberator and the passionate enthusiast. As such, we find citizens who participate in order to love, and a citizenship in which engagement inculcates the habits and desires of the scientific mind.

It is perhaps not surprising, then, that expressions of interest and pleasure within public engagement have been viewed with some suspicion within STS: are they simply a sign that lay participants are in some way complicit in the deficit model, and have capitulated to the cultural superiority of science? My second point is that this hesitation - this sense that public (and scientific) pleasure in science must be linked to uncritical submission to scientific hegemony - has led to a bracketing of these emotions within analyses of public engagement. This is despite the frequent citation of enjoyment or pleasure by those who participate in engagement activities as both motivation and reward for such participation (Besley et al., 2012; MartinSempere et al., 2008; Pearson, 1997; Rowe et al., 2010; Simonsson, 2006; Wilkinson et al., 2011). For instance, during my empirical research I have found that entertainment is implicit in the framing of informal public engagement, with organisers striving to design events which laypeople will, above all, attend, and ideally enjoy; that enjoyment is constantly cited by audiences and participants as a key feature of their experience (with interviews with these actors, at public engagement events or deliberative processes, almost invariably starting with some variation of: 'it's really good, I'm enjoying it'); and that the necessity of pleasurable affects is articulated with normative passion by communicators who argue not just that they know what their audiences want but that science-as-leisure can have profound effects on participants. Delight, interest, enthusiasm, and pleasure all leave their traces on the practice of public engagement (see also Pearson, 1997; Rowe et al., 2010; Simonsson, 2006; Wilkinson et al., 2011) - even those forms, such as consensus conferences, which are more formal, perhaps drier, in nature (Powell et al., 2011). It is worth, I think, running the risk of labouring this point. People (whether scientists or laypeople) generally participate in public engagement because they want to - because they find 
some satisfaction or enjoyment in talking about nanotechnology at a museum forum event, experiencing the spectacle of the Body Worlds exhibitions, or participating in a policy-oriented discussion. There is, we might say, a hedonism of science as leisure and pleasure, and it is this latent and largely unacknowledged reservoir of emotion that powers many of the encounters between scientific knowledges and publics.

Certainly, the critical accounts outlined above describe one dynamic - the shaping of supportive, uncritical citizens - in which these positive affects are implicated (Thorpe \& Gregory, 2010). The production of trust has been, and continues to be, an underlying (if not always acknowledged) motivation for some scientific and policy enthusiasm for engagement (Irwin et al., 2013; Wynne, 2006). Many scientists do think that interested publics will like science better, and become a more accepting market for its products (or perhaps be recruited into it; Besley et al., 2012; Davies, 2008). But is this dynamic the only one structuring expressions of interest, pleasure and delight? Can we understand them in any other terms?

I would suggest that pleasure in public engagement is indeed a more complex phenomenon - one that requires further attention in order to account for and understand its role and meaning within (different kinds of) engagement activity. I would like to briefly offer up two lines of thought which might help us start to do this - two potential vehicles for 'following' pleasure in public engagement, and which may act as thought-experiments with which to start to interrogate its affordances and effects. The first is taken from Isabelle Stengers' notion of the need to 'relearn' laughter (2000). In an essay concerned with how to criticise (or, better, intervene in) power - specifically, the power of "Science, Reason, Objectivity" (Stengers, 2000:
53) - without becoming ensnared within the very structures such power assumes, Stengers introduces the value of laughter. The injustices of power, she says, readily bring us to angry, serious denunciations - to critiques that run the risk that "one might accept the terms of the problem as they have been defined" (Stengers, 2000: 42). Laughter disrupts these relations: it stands outside, calling attention to the fictions which attend scientific truth claims (cf. Young, 2001). As such, she dreams of publics who will:

recognize and laugh at those [scientific] productions whose aim is to fascinate, to subordinate, or to win us over. This would obviously not suppress power relations. But it would complicate speculation. It would impose new constraints and multiply the risks for speculative scientists. It would at least destroy the appearance of neutral rationality used as a blind whenever there is a question of addressing the "incompetents." (Stengers, 2000: 51; italics in original)

Importantly, this laughter, though "mocking", is not simply derisive. Stengers emphasises the value of the interest of scientists, and is appreciative of its productions - but she is concerned that we do not take these productions too seriously. It is vital, she writes, that "we cease to be easily impressed" (p.51).

For Stengers, then, interest twinned with laughter can disrupt power relations, complicating the claims technoscience makes for itself and for its products (its 'speculations'). It is precisely when science is not taken too seriously that engagement with it becomes powerful: the combination of appreciative interest and humour enables the unpicking of the work that goes into the production of facts or promises and allows fun to be poked at whatever is grandiose and 
dictatorial (whether on the side of science or its "cohort of denunciators"; p.42). Perhaps, then, something along these lines may happen within public engagement - specifically that which emphasises entertainment, interest, and enjoyment. Perhaps - we might speculate - expressions of light-hearted pleasure open up space for an equally light-hearted negotiation of scientific claims. And in this regard we might draw a line to analysis of one experiment mentioned earlier: Maja Horst's dialogically-oriented public installation on stem cell research (Horst, 2011). A key outcome of this was exactly a public disregard for the solemnnities of dialogue, and a disruption of anticipated outcomes (Horst \& Michael, 2011). As in this example, respect for the humour of engagement may help us identify unexpected patternings of power.

Jane Bennett (2001) is also interested in the effects of a disposition of lightheartedness. Specifically, she is concerned with the ethical potential of enchantment, arguing that, firstly, the grand, Weberian narrative of a disenchanted modernity ignores pockets and streams of enchantment within modern life; and, secondly, that such moments of enchantment can give rise to the ethical work of generosity and grace. It is important, she writes, to:

heighten awareness of our profound and empowering - attachment to life. For such attentiveness can help transform shock at tragedy into a political will to reform painful social structures.

... My own sense is that the ethical and political potential within suffering is more likely to be realized if one's attention to suffering is infused by or remixed with the en-couraging [sic] experience of wonder. (Bennett, 2001: 160)
Thus, for Bennett, a state of enchantment can be a gateway to emancipatory action, providing "energy and inspiration" that enables individuals to, for instance, "enact ecological projects, or to contest ugly and unjust modes of commercialization" (Bennett, 2001: 174). She identifies a range of sites of such enchantment, including crossspecies encounters, Thoreau's Nature, and advertising campaigns; of most relevance to this discussion, however, is her interest in both the natural world - as it is revealed by "scientific practices and instruments" (Bennett, 2001: 171) - and technological artefacts such as computers, which can similarly "provoke wonder, surprise, and disorientation". Here wonder and delight can in and of themselves be an ethical good, opening the possibility of generosity to others (both human and nonhuman). For Bennett, then, lay exploration of robot pets or nanotechnology may provoke broader results than those encapsulated in science policy decisions or consensus reports, instead acting - at least potentially - to cultivate dispositions of generosity and ethical action. In her view delight in technoscience need not be automatically harnessed to neoliberalism and the cultural authority of science. Wonder may develop, in its participants, new sensitivities to tragedy and suffering. Again, it is helpful to point to concrete examples where this (may) be happening. The artist and academic Oron Catts, for instance, who runs the SymbioticA laboratory, ${ }^{12}$ has carried out a number of projects using tissue culture techniques, from creating a jacket of 'victimless leather' to collecting contemporary biological curiosities. These projects have the potential to fascinate and revolt in equal measure; they compel the viewer, but also force the opening up of new lines of ethical thought (what counts as life? How should we treat living stuff?). We might speculate that they induce wonder - but a 
wonder that disrupts rather than pacifies taken-for-granted assumptions, and which thereby energises the possibility of new modes of action around contemporary biological citizenship.

The lines of thought suggested by the work of Stengers and Bennett are, in part at least, empirical questions, dependent on the exact contours of pleasure within science-in-engagement. ${ }^{13}$ Once we have understood a little more of the pleasures of public participation - what is it, exactly, that provokes interest and enjoyment? How are these emotions expressed or suppressed? we may be able to speak more of its powers and effects. My point has thus not been to offer a categorical analysis of pleasure and delight in public engagement, but to illustrate the kinds of directions that being attentive to such emotions may take us in. Nor is my emphasis on these positive affects the only direction possible: as Harvey (2009) has noted, public participation may also be marked by more negative dynamics, such as frustration, rage, and humiliation. Following these - and other non-discursive aspects such the 'heaviness' of public engagement, its loadedness with sites and objects and stuff - is just as important as the need for a better understanding of pleasure and delight that I have pointed to here.

\section{Conclusion}

My aim in this article has been to provoke thought around what I have identified as a lacuna in the literature on public engagement with science. I have argued that STS analysis of public participation and engagement has tended to construe these practices as fundamentally discursive, and thus to render invisible the role of nondiscursive aspects, such as the material and affective, within them. In reflecting on this I have presented an overview of the literature on public engagement (noting that this has tended to explore the process, effects, framing or contexts of participation); discussed thinking from political theory which points to the importance of going beyond 'reasoned argument' within deliberation; and started to explore what it might look like to notice, and take seriously, public expressions of delight and interest in science within public engagement activities. While I inevitably have not done justice to the literatures on affect, materiality, and political theory that I have gestured to, and have used deliberately simplified outlines of their concepts, I hope I have shown that they offer productive lines of thought for the study of public engagement. My intention has been to build on the substantial body of knowledge STS has developed around public participation, and to suggest some new directions this scholarship might take. As such I have begun to outline, very sketchily, some possibilities for both empirical research and the practice of public engagement. Normatively - I have argued - we should try to incorporate the emotional, creative, aesthetic and embodied into our engagement practices; whilst empirically we need to be better at analysing these aspects of the processes we study.

\section{Acknowledgements}

This article is the result of many productive conversations with many people. I would like to thank in particular Cynthia Selin, Gretchen Gano, Ângela Guimarães Pereira, Maja Horst, Raffael Himmelsbach, Louise Whiteley, Adam Bencard, and Sebastian Mohr (the last three being members with me of a University of Copenhagen reading group on affect theory) - as well as the dialogue practitioner, some years ago, who commented to me that she was fed up with all this boringly worthy public engagement and thought that most people 
just wanted to have fun. I am also grateful for the comments of Science and Technology Studies' editors and reviewers. All errors remain my own.

\section{References}

Benhabib, S. (ed) (1996) Democracy and Difference: Contesting the Boundaries of the Political (Princeton: Princeton University Press).

Bennett, J. (2001) The Enchantment of Modern Life: Attachments, Crossings, and Ethics (Princeton: Princeton University Press).

Bennett, J. (2009) Vibrant Matter: A Political Ecology of Things (Durham, NC: Duke University Press).

Besley, J.C., Kramer, V.L., Qingjiang, Y. \& C. Toumey (2008) 'Interpersonal Discussion Following Citizen Engagement About Nanotechnology: What, If Anything, Do They Say?', Science Communication 30(2): 209-235.

Besley, J. C., Sang, H. O. \& M. Nisbet. (2013) 'Predicting Scientists' Participation in Public Life, Public Understanding of Science 22(8): 971-987.

Birchall, D. (2011) 'Things': a Case Study in Getting from Accession to Online Display in 60 Minutes (London: Electronic Visualisation and the Arts).

Blok, A. (2007) 'Experts on Public Trial: On Democratizing Expertise through a Danish Consensus Conference.' Public Understanding of Science 16(2): 163-182.

Bonney, R. H., Ballard, R., Jordan, E., McCallie, T., Phillips, J., Shirk, J. \& C.C. Wilderman (2009) 'Public Participation in Scientific Research: Defining the Field and Assessing Its Potential for Informal Science Education: A CAISE Inquiry Group Report' (Washington DC: Center for Advancement of Informal Science Education (CAISE).
Braun, B. \& S. Whatmore (ed) (2010) Political Matter: Technoscience, Democracy, and Public Life (Minnesota: U of Minnesota Press).

Braun, K. \& S. Schultz. (2010) “... a Certain Amount of Engineering Involved': Constructing the Public in Participatory Governance Arrangements', Public Understanding of Science 19(4): 403-419. Burri, R. V. (2009) 'Coping with Uncertainty: Assessing Nanotechnologies in a Citizen Panel in Switzerland, Public Understanding of Science 18(5): 498-511. __—. (2007) 'Deliberating Risks Under Uncertainty: Experience, Trust, and Attitudes in a Swiss Nanotechnology Stakeholder Discussion Group', NanoEthics 1(2): 143-154.

Bächtiger, A., Niemeyer, S., Neblo, M., Steenbergen, M.R. \& J. Steiner. (2010) 'Disentangling Diversity in Deliberative Democracy: Competing Theories, Their Blind Spots and Complementarities', Journal of Political Philosophy 18(1): 32-63.

Cameron, D. (2001) Working With Spoken Discourse (London: Sage).

Carolan, M. S. (2008) 'Democratizing Knowledge: Sustainable and Conventional Agricultural Field Days as Divergent Democratic Forms', Science, Technology \& Human Values 33(4): 508528.

Chambers, S. (2003) 'Deliberative Democratic Theory', Annual Review of Political Science 6(1): 307-326.

Cohen, J. (1989 ) 'Deliberation and Democratic Legitimacy.' In Alan Hamlin and Phillip Petit (eds) The Good Polity (London: Blackwell).

Davies, C., Wetherall, M. \& E. Barnett. (2006) Citizens at the Centre: Deliberative Participation in Healthcare Decisions (Bristol: Policy Press). 
Davies, S. R. (2013) 'Constituting Public Engagement: Meanings and Genealogies of PEST in Two U.K. Studies,' Science Communication. doi:10.1177/1075547013478203.

_-_. (2009) 'Doing Dialogue: Genre and Flexibility in Public Engagement with Science,' Science as Culture 18(4): 397416.

_-_. (2013) 'The Rules of Engagement: Power and Interaction in Dialogue Events,' Public Understanding of Science 22(1): 65-79.

Delgado, A., Kjolberg, K. \& F. Wickson. (2011) 'Public Engagement Coming of Age: From Theory to Practice in STS Encounters with Nanotechnology', Public Understanding of Science 20(6): 826-845.

Dryzek, J. S. (2000) Deliberative Democracy and Beyond. (Oxford: Oxford University Press.)

Dryzek, J. S., Goodin, R. E., Tucker, A. \& B. Reber. (2009) 'Promethean Elites Encounter Precautionary Publics: The Case of GM Foods', Science, Technology \& Human Values 34(3): 263-288.

Elam, M. \& M. Bertilsson. (2003) 'Consuming, Engaging and Confronting Science,' European Journal of Social Theory 6(2): $233-251$.

Endres, D. (2009) 'Science and Public Participation: An Analysis of Public Scientific Argument in the Yucca Mountain Controversy,' Environmental Communication: A Journal of Nature and Culture 3(1): 49-75.

Fairclough, N. (2003) Analysing Discourse: Textual Analysis for Social Research (Abingdon: Routledge).

Farmelo, G. (2003) It Must Be Beautiful: Great Equations of Modern Science. (London: Granta)
Felt, U., Fochler, M., Mager, A. \& P. Winkler. (2008) 'Visions and Versions of Governing Biomedicine: Narratives on Power Structures, Decision-making and Public Participation in the Field of Biomedical Technology in the Austrian Context,' Social Studies of Science 38(2): 233-257.

Felt, U., Fochler, F., Muller, A. \& M. Strassnig. (2009) 'Unruly Ethics: On the Difficulties of a Bottom-up Approach to Ethics in the Field of Genomics', Public Understanding of Science 18(3): 354-371.

Fiorino, D. J. (1990) 'Citizen Participation and Environmental Risk: A Survey of Institutional Mechanisms', Science Technology Human Values 15(2): 226243.

Gammon, B. \& A. Burch. (2003) Indicators of Dialogue (London: Science Museum).

Gottweis, H. (2008) 'Participation and the New Governance of Life', BioSocieties 3(3): 265-286.

Goven, J. (2003) 'Deploying the Consensus Conference in New Zealand: Democracy and De-Problematization', Public Understanding of Science 12(4): 423-440.

Gregg, M. \& G. J. Seigworth. (2010) The Affect Theory Reader (North Carolina: Duke University Press).

Gregory, J, \& S. J. Lock. (2008) 'The Evolution of 'Public Understanding of Science': Public Engagement as a Tool of Science Policy in the UK', Sociology Compass 2(4): 1252-1265.

Hagendijk, R. \& A. Irwin. (2006) 'Public Deliberation and Governance: Engaging with Science and Technology in Contemporary Europe', Minerva 44(2): 167-184.

Hamlett, P. W. (2003) 'Technology Theory and Deliberative Democracy', Science, Technology \& Human Values 28(1): 112140. 
Harvey, M. (2009) 'Drama, Talk, and Emotion: Omitted Aspects of Public Participation,' Science, Technology \& Human Values 34(2): 139-161.

Hilgartner, S. (2000) Science on Stage: Expert Advice as Public Drama (Stanford, Calif.: Stanford University Press).

Horlick-Jones, T., Walls, J., Rowe, G., Pidgeon, N., Poortinga, W. \& T. O'Riordan. (2006) 'On Evaluating the 'GM Nation?' Public Debate About the Commercialisation of Transgenic Crops in Britain', New Genetics and Society 25(3): 265-288.

Horlick-Jones, T., Walls, J., Rowe, G., Pidgeon, N., Poortinga, W., Murdock, G. \& Tim O'Riordan. (2007) The GM Debate: Risk, Politics and Public Engagement (New York: Routledge).

Horst, M. (2011) 'Taking Our Own Medicine: On an Experiment in Science Communication,' Science and Engineering Ethics 17(4): 801-815.

Horst, M. \& A. Irwin. (2010) 'Nations at Ease with Radical Knowledge: On Consensus, Consensusing and False Consensusness', Social Studies of Science 40(1): 105-126.

Horst, M. \& M. Michael. (2011) 'On the Shoulders of Idiots: Re-thinking Science Communication as 'Event", Science as Culture 20(3): 283-306.

Ingold, T. (2010) Bringing Things to Life: Creative Entanglements in a World of Materials. NCRM Working Paper \#15, ESRC National Centre for Research Methods.

Irwin, A. (2001) 'Constructing the Scientific Citizen: Science and Democracy in the Biosciences', Public Understanding of Science 10(1): 1-18.

___. (2006) 'The Politics of Talk: Coming to Terms with the 'New' Scientific Governance,' Social Studies of Science 36(2): 299-320.
Irwin, A., Jensen T. E. \& K. E. Jones. (2013) 'The Good, the Bad and the Perfect Criticizing Engagement Practice', Social Studies of Science 43(1): 118-135.

Irwin, A. \& M. Michael. (2003) Science, Social Theory and Public Knowledge. (Maidenhead: Open University Press)

Jasanoff, S. (2003) 'Technologies Of Humility: Citizen Participation In Governing Science', Minerva 41: 223-244. Joly, P. B. \& A. Kaufmann. (2008) 'Lost in Translation? The Need for Upstream Engagement with Nanotechnology on Trial', Science as Culture 17(3): 225-247.

Katz, E., Solomon, F., Mee, W. \& R. Lovel. (2009) 'Evolving Scientific Research Governance in Australia: a Case Study of Engaging Interested Publics in Nanotechnology Research', Public Understanding of Science 18(5): 531-545.

Kerr, A., Cunningham-Burley, S. \& R. Tutton. (2007) 'Shifting Subject Positions: Experts and Lay People in Public Dialogue, Social Studies of Science 37(3): 385-411.

Kleinman, D. L., Delborne, J. A. \& A. A. Anderson. (2011) 'Engaging Citizens', Public Understanding of Science 20(2): $221-240$.

Kurath, M. \& P. Gisler. (2009) 'Informing, Involving or Engaging? Science Communication, in the Ages of Atom, Bio- and Nanotechnology', Public Understanding of Science 18(5): 559-573. Kurian, P. \& J. Wright. (2012) 'Science, Governance, and Public Participation: An Analysis of Decision Making on Genetic Modification in Aotearoa/ New Zealand, Public Understanding of Science 21(4): 447-464. 
Lassen, I., Horsbøl, A., Bonnen, K. \& A. G. J. Pedersen. (2011) 'Climate Change Discourses and Citizen Participation: A Case Study of the Discursive Construction of Citizenship in Two Public Events', Environmental Communication: A Journal of Nature and Culture 5: 411-427.

Latour, B. (2000) 'When Things Strike Back: a Possible Contribution of 'science Studies' to the Social Sciences', The British Journal of Sociology 51(1): 107123.

Latour, B. \& P. Weibel (eds) (2005) Making Things Public: Atmospheres of Democracy (Cambridge Mass: MIT Press; ZKM/Center for Art and Media in Karlsruhe).

Lehr, J. L., McCallie, E., Davies, S. R., Caron, B. R., Gammon, B. \& S. Duensing. (2007) 'The Role and Value of Dialogue Events as Sites of Informal Science Learning, International Journal of Science Education 29(12): 1-21.

Lengwiler, M. (2008) 'Participatory Approaches in Science and Technology: Historical Origins and Current Practices in Critical Perspective,' Science, Technology \& Human Values 33(2): 186200.

Leys, R. (2011) 'The Turn to Affect: A Critique.' Critical Inquiry 3(3): 434-472.

Lezaun, J. \& L. Soneryd. (2007) 'Consulting Citizens: Technologies of Elicitation and the Mobility of Publics,' Public Understanding of Science 16(3): 279-297. Lyons, K. \& J. Whelan. (2010) 'Community Engagement to Facilitate, Legitimize and Accelerate the Advancement of Nanotechnologies in Australia, NanoEthics 4(1): 53-66.

Macnaghten, P. \& J. S. Guivant. (2011) 'Converging Citizens? Nanotechnology and the Political Imaginary of Public Engagement in Brazil and the United Kingdom,' Public Understanding of Science 20(2): 207-220.
Marres, N. (2012) Material Participation: Technology, the Environment and Everyday Publics (London: Palgrave Macmillan).

___. (2009) 'Testing Powers of Engagement: Green Living Experiments, the Ontological Turn and the Undoability of Involvement,' European Journal of Social Theory 12(1): 117-133.

Martin, T. (2007) 'Muting the Voice of the Local in the Age of the Global: How Communication Practices Compromised Public Participation in India's Allain Dunhangan Environmental Impact Assessment', Environmental Communication: A Journal of Nature and Culture 1(2): 171.

Massumi, B. (1995) 'The Autonomy of Affect', Cultural Critique 31: 83-109.

Mayer, S. (2003) GM NATION? Engaging People in Real Debate? A GeneWatch UK Report on the Conduct of the UK's Public Debate on GM Crops and Food. (Buxton: Genewatch UK)

McCallie, E., Simonsson, E., Gammon, B., Nilsson, K., Lehr, J.L. \& S. R. Davies. (2007) 'Learning to Generate Dialogue: Theory, Practice, and Evaluation, Museums and Social Issues 2(2): 165184.

Michael, M. (2011) 'Affecting the Technoscientific. Body Stem Cells, Wheeled-Luggage and Emotions', Technoscienza 2(1): 53-64.

_-_. (2012) 'What Are We Busy Doing?' Engaging the Idiot', Science, Technology \& Human Values 37(5): 528-554.

Miller, D. (2005) Materiality (North Carolina: Duke University Press Books). Mouffe, C. (2002) Politics and Passions: The Stakes of Democracy (London: Centre for the Study of Democracy).

Neresini, F. \& M. Bucchi. (2010) 'Which Indicators for the New Public Engagement Activities? An Exploratory Study of European Research Institutions', Public Understanding of Science 20(1): 64-79. 
Nye, D. E. (1996) American Technological Sublime (Cambridge: MIT Press).

Pearson, G., Pringle, S. M. \& J. N. Thomas. (1997) 'Scientists and the Public Understanding of Science', Public Understanding of Science 6(3): 279-289.

Pestre, D. (2008) 'Challenges for the Democratic Management of Technoscience: Governance, Participation and the Political Today', Science as Culture 17(2): 101-119.

Powell, M., Delborne, J. \& M. Colin. (2011) 'Beyond Engagement Exercises: Exploring the US National Citizens' Technology Forum from the Bottom-Up', Journal of Public Deliberation 7(1): 4 .

Powell, M. \& D. Kleinman. (2008) 'Building Citizen Capacities for Participation in Nanotechnology Decision-making: The Democratic Virtues of the Consensus Conference Model,' Public Understanding of Science 17(3): 329-348.

PytlikZillig, L. M. \& A. J Tomkins. (2011) 'Public Engagement for Informing Science and Technology Policy: What Do We Know, What Do We Need to Know, and How Will We Get There?' Review of Policy Research 28(2): 197-217.

Rowe, G. \& L. J. Frewer. (2000) 'Public Participation Methods: A Framework for Evaluation', Science, Technology \& Human Values 25(1): 3-29.

Rowe, G., Marsh, R. \& L. J. Frewer. (2004) 'Evaluation of a Deliberative Conference,' Science, Technology \& Human Values 29(1): 88-121.

Rowe, G., Rawsthorne, D., Scarpello, T. \& J. R. Dainty. (2010) 'Public Engagement in Research Funding: a Study of Public Capabilities and Engagement Methodology, Public Understanding of Science 19(2): 225-239.

Sandercock, L. (2003) Cosmopolis II: Mongrel Cities in the 21st Century (London; New York: Continuum).
Sanders, L. M. (June 1997) 'Against Deliberation', Political Theory 25, no. 3: 347-376.

Schibeci, R., Harwood, J. \& H. Dietrich. (2006) 'Community Involvement in Biotechnology Policy?: The Australian Experience', Science Communication 27(3): 429-445.

Schibeci, R. \& J. Harwood. (2007) 'Stimulating Authentic Community Involvement in Biotechnology Policy in Australia, Public Understanding of Science 16(2): 245-255.

Sedgwick, E. K. \& A. Frank. (1995) 'Shame in the Cybernetic Fold: Reading Silvan Tomkins', Critical Inquiry 21(2): 496-522.

Simonsson, E. (2006) Dana Centre Audience Research Report 2005-2006 (London: Visitor Research Group, Science Museum).

Stengers, I. (2000) 'Another Look: Relearning to Laugh', Hypatia 15(4): 4154.

Thorpe, C. (2010) 'Participation as PostFordist Politics: Demos, New Labour, and Science Policy', Minerva 48(4): 389-411.

Thorpe, C. \& J. Gregory. (2010) 'Producing the Post-Fordist Public: The Political Economy of Public Engagement with Science,' Science as Culture 19(3): 273301.

Tomkins, S. S. (1962) Positive Affects (New York: Springer Publishing Company).

Turney, J. (1998) To Know Science Is to Love It? Observations from Public Understanding of Science Research (London: COPUS).

Walmsley, H. (2010) 'Biobanking, Public Consultation, and the Discursive Logics of Deliberation: Five Lessons from British Columbia,' Public Understanding of Science 19(4): 452-468.

Ward, V., Howdle, P. \& Susan Hamer. (2008) 'You \& Your Body', Science Communication 30(2): 177. 
Webster, S. (2005) 'Art and Science Collaborations in the United Kingdom, Nat Rev Immunol 5(12): 965-969.

Wehling, P. (2012) 'From Invited to Uninvited Participation (and Back?): Rethinking Civil Society Engagement in Technology Assessment and Development,' Poiesis \& Praxis 9(1-2): 43-60.

Wetherell, M. (2012) Affect and Emotion: A New Social Science Understanding (London: SAGE).

Wilkinson, C., Dawson, E. \& K. Bultitude. (2011) "Younger People Have Like More of an Imagination, No Offence': Participant Perspectives on Public Engagement.' International Journal of Science Education Part B 2(1): 43-61.

Wynne, B. (1992) 'Misunderstood Misunderstanding: Social Identities and Public Uptake of Science,' Public Understanding of Science 1(3): 281-304. _-_. (2006) 'Public Engagement as a Means of Restoring Public Trust in Science -- Hitting the Notes, but Missing the Music?' Community Genetics 9(3): 211-220.

Young, I. M. (2001) 'Activist Challenges to Deliberative Democracy', Political Theory 29(5): 670-690.

Sarah R. Davies

Institut for Medier, Erkendelse og

Formidling

Det Humanistiske Fakultet

Københavns Universitet

Karen Blixens Vej 4, DK-2300, København S dxq327@hum.ku.dk

\section{Notes}

1 In this article I use the terms 'discursive' and 'non-discursive' to refer to 'language in use' (or not). This is the sense in which they are used in linguistics and the types of discourse analysis primarily influenced by it (see Cameron 2001), and should be differentiated from other, broader understanding of the discursive, in which discourses are not necessarily tied to language (Fairclough 2003).

2 Throughout this paper I treat the terms public engagement with science, public participation, and dialogue as effective cognates. Though it is possible to parse out differences between them (and indeed between different practices which use the same nomenclature), there has been a general move towards the use of participatory and deliberative techniques which has impacted, for instance, science policy, STS, and science communication. See discussions in Delgado et al. (2010), Hagendijk and Irwin (2006), Lehr et al. (2007) and Lengwiler (2008).

3 I focus on the European - and more specifically the UK - context in this paper, though similar developments are occurring in the US (Bonney et al., 2009).

4 One of the reviewers pointed out that dialogue events are not neccessarily "dramatic and emotional", but may also be rather dry and mundane. While this is certainly the case, it is worth bearing in mind that the dryest event still has performative and dramaturgical aspects (Hilgartner, 2000) - and that boredom, ennui and the quotidien have affective as well as discursive dimensions.

5 In addition, the affect/emotion distinction is itself not unproblematic and has been subject to much debate. See Leys (2011) for one STS-inflected critique and Wetherell (2012) for a helpful overview.

6 Though, as the paper progresses, it will become clear that my interest in the case study of the role of pleasure in public engagement that I begin to 
work through is primarily with emotion rather than with the more subtle workings of affect.

7 The key exception being Marres' work on 'material participation' (2009; 2012). However, Marres explicitly focuses on forms of participation that are overtly and deliberately oriented towards innovative material configurations, such as smart meters and other 'green living' experiments in the home; she is interested in efforts to "locate public engagement with environmental issues in everyday material practice" (Marres, 2012: 3). This is slightly different to the analysis of science communication and policy-oriented deliberation where materiality, both as explicit subject matter and implicit configuration, has been rendered invisible.

8 A position which can itself, of course, be critiqued: are any interactions truly free from coercion (Mouffe, 2002)?

9 See http://www.stamcellenetvaerket. $\mathrm{dk} /$ eng-installation $1 . h t m$

$10 \mathrm{http}: / /$ syntheticaesthetics.org/about

11 Though there are again some obvious avenues to follow, including asking: what different materialities are implicated in different forms of participation? What emotions do participants report? What role do nonhuman actants play in co-constructing the outcomes of deliberation? Methodological traditions from both STS (for instance, lab ethnographies) and social psychology (which is increasingly turning its attention to the study of 'affective practices'; Wetherell, 2012) offer additional lines of thought.

12 See http://www.symbiotica.uwa.edu. au and http://tcaproject.org

13 They also require further contextualisation and theorisation. Both lines of thought are sketches, only, and would benefit from further development. One reviewer made the point, for example, that both can be situated within longer traditions: of the 'idiot' or fool, in the case of Stenger's interest in laughter (cf Michael 2012); and of the sublime, in the case of Bennett's analysis (see Nye, 1996). We might also look to the long history of notions of beauty, elegance and love within scientific practice, from Poincaré's comments that "The scientist does not study nature because it is useful to do so. He studies it because he takes pleasure in it, and he takes pleasure in it because it is beautiful. If nature were not beautiful it would not be worth knowing, and life would not be worth living" to Graham Farmelo's book It must be beautiful (2003), which argues for the essential elegance of important scientific equations. 